\title{
Internet Case: Mengkaji Makna Cyberbullying
}

\author{
Intan Kurnia Syaputri*
}

\begin{abstract}
Internet users are increasingly increasing and online interactivity is also increasing, this internet usage certainly has a negative impact. One of the impacts is the phenomenon of cyberbullying. Cyberbullying has four elements: willful, repeated, harm and computers cell phones, and other electronic devices. Power on cyberbullying comes from the ability, knowledge and ownership of some content. The content can be in the form of information or images used to carry out cyberbullying actions. Victims of cyberbullying tend not to protect themselves, due to imbalance power. In many ways, the "harm" effect caused by cyberbullying is considered more dangerous because of anonymity on the internet that allows cyberbullying agents to cover their identity.
\end{abstract}

Keywords : Internet, Cybercrime, Bullying, Cyberbullying

\section{A. Latar Belakang}

Information and Communication

Technology (ICT) atau dalam bahasa

Indonesia disebut sebagai Teknologi

Infomasi dan Komunikasi (TIK), adalah payung besar terminologi yang mencakup seluruh peralatan teknis untuk memproses dan menyampaikan informasi. TIK mencakup dua aspek yaitu teknologi informasi dan teknologi komunikasi. Seperti yang dikatakan Everett $\mathbf{M}$ Rogers: "The hardware equipment, organizational structures and social values by which individuals collect, process and exchange information with other individuals"

Dapat diartikan bahwa teknologi informasi merupakan perangkat keras yang bersifat organisatoris dan meneruskan nilai-nilai sosial dengan siapa individu atau khalayak mengumpulkan, memproses dan saling mempertukarkan informasi dengan individu atau khalayak lain. Oleh karena itu, teknologi informasi dan teknologi komunikasi adalah dua buah konsep yang tidak terpisahkan. Perkembangan ICT juga menjadi pendukung adanya perkembangan internet yang sangat luar biasa.

Seperti diungkapkan oleh Flew (2005)," The Internet represents the newest,most widely discussed, and perhaps most significant manifestation of new media." 2

Internet memang sangat fenomenal karena pada era telepon kabel dahulu tidak terbayangkan pada masa depan kabelkabel telepon tersebut dapat memunculkan 
gambar, tidak hanya suara dan nyatanya internet pun berkembang terus.Awalnya internet dimanfaatkan untuk email dan situs, kemudian dimanfaatkan untuk blog, situs jejaring sosial, situs berbagi video, televisi internet, konferensi video, game online dan lain-lain.

Perkembangan internetdalam kehidupan sehari-hari juga menyebabkan perkembangan masyarakat informasi. Everett M. Rogersmenjelaskan tentang pengertian masyarakat informasi, " $A n$ information society is a nation in which a majority of labor force is composed of information workers an in which information is the most important element. "3alam definisi ini digambarkan bahwa masyarakat informasi merupakan suatu bangsa yang dimana sebagaian besar pekerjaanya terdiri dari beberapa pekerja informasi, dimana informasi tersebut menjadi suatu elemen yang paling penting. "pekerja informasi” diartikan Rogers sebagai seseorang yang memliki aktivitas utama yaitu membuat, mengolah atau menyampaikan informasi.

Namun, pertumbuhan masyarakat informasi ini juga disertai dengan ancaman yang cukup serius. Sebagaimana lazimnya, perkembangan teknologi internet juga memberikan akses negatif dengan terbukanya peluang penyalahgunaan teknologi. Di internet, masalah kriminalitas semakin kompleks karena ruang lingkupnya yang luas. Kriminalitas di internet atau yang disebut sebagai cybercrime ini misalnya praktik penipuan online, pornografi, maraknya kejahatan yang dilakukan hacker dan cyberbullying. ${ }^{4}$ Cyber crime didefinisikan sebagai "under this definition, cyber crime is merely a sub-set of conventional crime whereICTs are used as a vehicle or tool to commit traditional criminal offences",5 kejahatan di internet sama halnya dengan kejahatan konvensional, yang dalam hal ini teknologi digunakan sebagai kendaraan/alat untuk melakukan suatu tindakan kejahatan tersebut. Klasifikasi cybercrime ini menyangkut kejahatan terhadap individu, kejahatan terhadap properti, kejahatan terhadap organisasi dan kejahatan terhadap masyarakat. ${ }^{6}$ Dalam tulisan ini, penulis berfokus untuk mengkajimengenaiistilah cybercrime yang ditujukan terhadap crime against individuals/kejahatan terhadap individu. Crime against individuals seperti kasus cyberbullying yang terjadi melalui jaringan internet, karena kasus-kasus seperti ini marak terjadi di Indonesia.

\section{B. Tinjauan Teoritis}

\section{Reinterpretasi Internet dan Cybercrime}

Sejarah internet dimulai pada tahun 1969ketika Departemen Pertahanan Amerika memutuskan untuk mengadakan riset tentang metode menghubungkan 
sejumlah komputer sehingga membentuk jaringan organik. Tujuannya untuk membuat sistem jaringan komputeryang tersebar,yang berguna untuk mengatasi masalah bila terjadi serangan nuklir dan menghindari informasi terpusat.Program riset ini dikenal dengan nama ARPANET. ${ }^{7}$ Selama bertahun-tahun kemudian, internet hanya digunakan di lingkungan sains dan militer. Parailmuwan menggunakan internet untuk bertukar informasi, penyebaran jurnal, akses komputerjarak jauhdan email. Aplikasiaplikasi tersebut berjalan dengan baik di atas model datagram. Namun, semenjak TimBerners-Lee pada tahun 1990 memperkenalkanteknologi World Wide Web(WWW), internet mengalami perubahan yang luar biasa. ${ }^{8}$

Internet menjadi milik publik dan menjelma menjadi jaringan komputer terbesar di dunia. Berbagaiaplikasi baru pun bermunculan, seperti VoIP, video conference, game online dan situs jejaring sosial. Ditambah lagi infrastruktur komunikasi modernnya yang juga semakin berkembang. Komputer yang digunakan untuk mengakses internet dulu harus menggunakan kabel telepon, namun sekarang semuanya terasa semakin canggih. Ditambah lagi infrastruktur komunikasi modernnya yang juga semakin berkembang. Komputer yang digunakan untuk mengakses internet dulu harus menggunakan kabel telepon, namun sekarang semuanya terasa semakin canggih.

Internet juga memungkinkan penduduk dunia memasuki era perdagangan digital atau e-commerce. Seperti yang diungkapkan oleh Jawkes Yvoone dan Majid, padamilenium ketiga internet telah menjadi bagian dari gaya hidup sebagian masyarakat dunia.Internet bisa dikatakan menciptakan ruang atau dunia baru bagi manusia untuk berekspresi dan berkomunikasi. Dunia baru itu biasa disebut dunia cyber space atau dunia maya, sebuah ruang ketika penggunanya bisa berbagi dan berkomunikasi tanpa dibatasi oleh wilayah dan kewarganegaraan. ${ }^{9}$ Di dalam dunia maya bisa ditemukan akses ke berbagai materi pengetahuan dan budaya yang ada di belahan dunia lain. Didalamnya juga terdapat materi hiburan, seperti musik, videodan film. Penggunanya bisa bertemu teman lama, kerabat jauh, bahkan pasangan hidup.

Dari penjelasan diatas, perlu diperhatikan bahwa di dunia maya juga terdapat berbagai materi yang terlarang, seperti data intelijen yang mengandung rahasia negaradan materi pornografi yang bisa merusak moral. Hal ini bisa disebut sebagai kejahatan melalui internet yang menyalahgunakan kecanggihan teknologi. Hal ini juga bisa diartikan bahwanew 
criminalitydi internet adalahsebuah ancaman yang paling signifikan di globalisasi internet. Internet, web dan cyberspace digambarkan sebagai bentukbentuk baru dari kriminalitas.Seperti yang diungkapkan Jawkes,conventional crime sendiri diartikan sebagai suatu tindakan yang dilakukan melanggar hukum dan siapa yang melanggar dikenakan hukuman. Kejahatan adalah fenomena sosial dan ekonomi, kejahatan merupakan konsep hukum yang legal/sah dan memiliki sanksi hukum.Sedangkan istilah cybercrime ini mengarah pada kejahatan yang dilakukan menggunakan bantuan dari kecanggihan teknologi. Adanya teknologi informasi yang canggih ditambah lagi dengan munculnya internet generasi kedua yang disebut web 2.0 membuat semua orang bisa mendapatkan informasi yang sangat banyak dan luas. ${ }^{10}$ Dengan adanya jaringan komunikasi digital ini ledakan kriminalitas online pun juga terjadi.

Untuk memetakan pemahaman, kita memerlukan batasan tentang fenomena new criminality. Seperti fenomena di internet, penyimpangan yang terjadi tidak hanya dilihat dari kejahatan digital. Namun kita juga harus menangkap adanya karakteristik yang penting dari new criminality di internet ini. Internet merupakan sebuah teknologi yang cepat dalam penyampaian informasi dan menciptakan adanya dunia maya
(cyberspace).Seperti yang dijelaskan oleh Jawkes, terdapat dua karakteristik dari cybercrime yaitu digitalisasi dan anonimitas. ${ }^{11}$ Digitalisasi melalui jaringan internet memungkinkan percepatan pengiriman informasi.Kedua, anonimitas di cyberspace, anominitas ini sebagai efek dari adanya pertemuan dan hubungan melalui dunia maya. Misalnya dari web 2.0 ada youtobe, myspace, facebook, twitter dll.Identitas yang dibangun didunia maya merupakan informasi yang dibuat sendiri oleh pengguna biasanya banyak yang memanipulasi identitas diri mereka di duni virtual.

Cybercrime merujuk pada semua jenis kejahatan yang mengeksploitasi jaringan telekomunikasi modern ${ }^{12}$, dimana komputer beserta jaringannya digunakan sebagai alat untuk melakukan kegiatan kriminal. Ada banyak jenis kejahatan cybercrime yang salah satunya adalah kejahatan yang menyerang individu (Crime Against Individu) seperti cyberbullying. Pada bagian selanjutnya akan dibahah lebih dalam mengenai pengertian dari cyberbullying.

\section{Mengkaji MaknaCyberbullying}

Cybercrime merupakan bentukbentuk kejahatan yang timbul karena pemanfaatan teknologi internet, banyak jenis dari kejahatan cybercrime seperti yang telah dijelaskan pada bagian sebelumnya.Cyber bullying merupakan 
sebuah fenomena baru dari perkembangan teknologi komunikasi. Penulis ingin membahas cyberbullying karena melihat fenomena cyberbullying ini telah meresahkan masyarakat yang lainnya. Jika melihat kasus-kasus cybercrime yang lain seperti hacker, penipuan melalui internet, pornografi dan lain sebagainya telah kita ketahui sejak lama. Pada saat ini, cybercrime telah merambah kepraktik bullying terhadap individu atau kelompok. Telah banyak contoh kasus cyberbullying yang terjadi di Indonesia, dimana hal ini akan dijelaskan pada bagian selanjutnya. Cyberbullying muncul seiring dengan perkembangan teknologi informasi dan komunikasi. Wabah bullying yang semula hanya terjadi dari pertemuan fisik ini telah menemukan lapangan baru yang membuat pelaku bullying lebih leluasa melakukan tindakan ini tanpa pertemuan langsung di dunia nyata. Dari tahun ke tahun, cyberbullying berkembang menjadi tindakan yang dilakukan seseorang untuk mengintimidasi, menyakitkan hati, mengancam atau mempermalukan sesama anggota dunia maya.

Dunia maya memberikan suatu kenyamanan tersendiri yang memperlengka pemain dengan privasi dan fasilitas yang tersedia khususnya di media sosial. Ditambah lagi banyaknya masyarakat Indonesia yang memiliki akun media sosial. Tren penggunaan media sosial inilah yang menyebabkan cyberbullying terjadi.Humphery, Robert dan Petta mendefinisikan cyberbullying sebagai pengirimkan pesan/informasi melalui komputer atau perangkat elektronik lainnya yang ditujukan kepada seseorang dan menyebabkan pelecehan terhadap mereka yang dituju. Cyberbullying research center mendefinisikan cyberbullying sebagai "willful and repeated harm inflicted through the use of computers, cell phones, and other electronic de-vices." 13 yang artinya kejahatan yang dilakukan dengan disengaja melalui penggunaan komputer, telepon dan perangkat elektronik lainnya. Menurut Cyber Bullying Research Centerunsur-unsur dari cyberbullying ini meliputi "willful" yang berarti perilaku atau tindakan yang disengaja, "repeated" yang berarti diulang-ulang dan mencerminkan sebuah pola perilaku, bukan hanya berupan satu insiden tunggal yang terjadi, dan kemudian "harm"yang memiliki arti sebagai sebuah ancaman, kejahatan atau tindakan yang menyakiti yang ditujukan pada korbannya dan yang terakhir adalah unsur "computers, cell phones, and other electronic devices" merupakan sebuah media yang dipakai untuk melakukan tindakan cyberbullying, hal ini yang kemudian juga merupakan suatu hal yang membedakan cyberbullying dari bullying secara tradisional. 
Kemudian, istilah bullying telah dikenal sejak lama, fenomena bullying ini petama kali dibahas oleh Heinemann pada tahun 1973. Heinemann menggunakan istilah Norwegia, mobbning untuk menjelaskan apa itu bullying, dimana mobbning ini berarti kekerasan yang dilakukan oleh sekelompok individu pada seorang individu. Istilah ini juga digunakan dalam literatur Jerman, namun kemudian ada penambahan definisi yang dilakukan oleh Olweus, dimana pada awalnya dia juga menggunakan terminologi yang sama dalam menjelaskanapa itu bullying, lebih jauh lagi akhirnya Olweus menambahkan systematic one-on-one attacks of stronger child against weaker childdalam definisi dari bullying itu sendiri. ${ }^{14}$

Perkembangan dari pendefinisian bullying ini dari tahun ketahun ikut mengalamiperubahan, dimana pada tahun 1999 Olweus kembali lagi menyempurnakan definisi daribullyingini dengan menandai bullying dengan tiga kriteria, yang pertamaaggressive behavior or intentional harmdoing, lalu yang kedua carried repeatedy and over timedan yang ketiga adalah interpersonal relationship characterized by an imbalance of power. ${ }^{15}$ Dari tiga kareakteristik yang dikemukakan oleh Olweus menunjukan bahwa bullying merupakan sebuah tindakan yang bersifat agresif yang dilakukan secara sengaja dan berulangulang dimana pelaku dan korbannya memiliki kekuatan fisik yang tidak seimbang. Selain itu Olweus juga menyebutkan bahwa bullyingberupa kegiatan negatif yang dapat terwujud dalam bentuk kontak fisik, kata-kata, gerak tubuh dan pengucilan seseorang dari satu kelompok tertentu yang kemudian definisi dari Olweus ini banyak diterima oleh para peneliti lainnya.

Dari definisi ini, menjelaskan bahwabullying merupakan suatu aggressive act, namun tidak hanya agrresive act dalam bullying juga terdapat unsur tambahan yang berupa imbalance of power and repetition. Dengan penjelasan ini menunjukkan bahwa bullying berbeda dengan bentuk agresi lainnya, dimana tidak semua bentuk agresi ataupun kekerasan dapat dikategorikan sebagai bullying. Sebagai contoh, bentuk pertikaian atau perkelahian antara dua orang dengan kekuatan yang sama merupakan suatu bentuk agresi atau kekerasan, namun hal ini bukanlah suatu bullying. Dalam bullying terdapat imbalance of power dimana korban dari bullying ini cenderung mengalami kesulitan dalam melindungi dirinya sendiri. Dari definisi ini juga menegaskan bahwa bentuk godaan yang dilakukan oleh individu terhadap individu lain bukanlah suatu bentuk bullying. 
Seperti halnya dalam bullying tradisional, dalam cyberbullying juga terdapat "power"yang membedakan antara pelaku dan korbannya. Permasalahan mengenai perbedaan power tidak termasuk dalam definisi diatas, hal ini dikarenakan powerdalam cyberbullying sifatnya dapat bergeser, sangat berbeda dengan power yang ada dalam bullying secara tradisional, dimana dalam bullying tradisional power sering kali berupa bentuk fisik atau posture dan juga power secara sosial yang dapat berupa popularitas. Sedangkan dalam cyberbullying, power cenderung berasal dari kemampuan, pengetahuan dan juga kepemilikan akan beberapa konten yang dapat berupa informasi ataupun gambar yang digunakan untuk melakukan tindakan cyberbullying. ${ }^{16}$

$$
\text { Cyberbullying }
$$

memiliki kecenderungan mendasar yang sama dengan bullying secara tradisional, dimana para korbannya juga cenderung tidak dapat melindungi dirinya sendiri, dikarenakan adanya imbalance poweryang ada. Dalam banyak cara, efek "harm" yang ditimbulkan dari cyber bullying dianggap lebih berbahaya daripada efek yang ditimbulkan oleh bullying secara tradisional. Efek harm yang ditimbulkan dianggap lebih berbahaya dikarenakan adanya anonimitas dalam internet yang memungkinkan para pelaku cyber bullying dapat menutupi indentitas dirinya.
Kemudian bisa menjadi semakin parah karena dalam internet terkadang terdapat unknown friends dari para pelaku yang merupakan orang-orang yang memiliki paham yang sama dengan pelaku, dan pada akhirnya mereka bersatu dan turut membantu untuk melakukan cyberbullying pada korbannya. Hal ini dilakukan para pelaku cyberbullying dan juga para unkown friends tersebut tanpa ada rasa takut akan pembalasan dan juga tuntutan yang dapat diajukan padanya, semua ini dikarenakan adanya anonimitas tersebut yang membuat identitas para pelaku ini tidak dikatuhi oleh korbannya. Dari pemahaman ini, cyberbullying dapat mengancam siapa saja, dan dimana saja tanpa melihat batas-batas negara. Contoh yang paling sering ditemukan adalah praktik cyberbullying pada public figure, hal ini akan dijelaskan secara mendalam pada bagian selanjutnya.

\section{Pembahasan}

\section{Praktik Cyberbullying di Indonesia}

Dilihat dari fenomena di dunia maya yang sering terjadi khususnya melihat praktik cyberbullying di Indonesia. Data Unicef memaparkan bahwa 30 juta anak Indonesia usia antara 10 hingga 18 tahun memiliki akses terhadap internet. Dari berbagai dampak positif yang ditawarkan internet, ternyata dimanfaatkan untuk ajang bully antar teman dan bahkan 
public figure sekalipun. Dari data yang disampaikan, persentase yang relatif tinggi adalah anak-anak yang menjadi korban cyberbullying. Hanya $42 \%$ responden menyadari risiko ditindas secara onlineselebihnya tidak. ${ }^{17}$

Sedangkan, berdasarkan survey IPSOS tahun 2011 di 24 Negara termasuk Indonesia, didapati bahwa $12 \%$ orang tua melaporkan anak mereka mengalami bullying, sekitar $60 \%$ menyatakan alat yang digunakan ialah Facebook. ${ }^{18}$ Dari 24 Negara ini, Indonesia merupakan Negara yang mempunyai tingkat kesadaran tertinggi terhadap praktik pembullyan melalui internet, dengan presentasi sebanyak $91 \%$. Fakta diatas menunjukan bahwa cyberbullying sudah menjadi masalah atau kejahatan yang sudah tidak jarang lagi dirasakan oleh pengguna internet. Bukan hanya anak-anak saja yang menjadi korban, public figure saat ini juga sering menjadi sasaran empuk praktik cyberbullying.

Misalnya di media sosial Instagram, beberapa public figureyang baru-baru ini menjadi sasaran empuk penindasan maya menimpa Bowo Alpenieble dan dua orang penyanyi dangdut Indonesia, yaitu Ayu Tingting dan Iis Dahlia. Menurut KBBI, public figurediartikan sebagai sentral yang menjadi pusat perhatian, ${ }^{19}$ dari pengertian ini, tak heran jika hal ini yang menjadi pemicu public figure mengalami kejahatan cyberbullying. Sebagai public figure yang dikenal oleh masyarakat luas, tentu segala aktivitas online yang dilakukan dapat dilihat dan menjadi perhatian khusus oleh pengguna internet lain. Ditambah lagi dengan adanya perubahan pengguna, pengguna tidak dapat lagi diartikan sebagai individu yang hanya menerima/menyimak sebuah informasi yang disuguhkan. Makna yang terurai mengenai "pengguna" sekarang amatlah kompleks.

Seperti yang dijelaskan oleh Wilkinson, McClung, \& Sherring, perubahan-perubahan yang terjadi, jelas mengartikan bahwa audiens yang dulunya "pasif" perlahanpun menjadi "aktif", hal ini karena konvergensi teknologi telah menggabungkan media massa, internet, dan world wide web menjadi teknologi yang praktis bagi audiensnya, sehingga batas antara komunikasi antarmanusia dan komunikasi massa mulai terhapus. ${ }^{20}$ Belum lagi ketika berbicara mengenai platform yang digunakan oleh pengguna, yang sebenarnya menjadi wadah terjadinya praktik cyberbullying.

Media sosial yang sering melancarkan praktik penindasan secara online kepada public figure sekarang adalah Instagram. Instagram, merupakan media sosial yang sangat banyak diminati masyarakat dunia. Indonesia menyumbang 
lebih dari $6 \%$ dari 700 juta pengguna aktif bulanan Instagram, atau pengguna Instagram di Indonesia berjumlah lebih dari 42 juta orang. ${ }^{21}$ Cara kerja media sosial ini dengan pengguna mengunggah foto yang ingin ditampilkan di akun Instagramnya, kemudian siapa pun bisa melihat foto, memberi tanda 'love' (menyukai unggahan foto), dan bisa member komentar di kolom komentar. Sesama pengguna bisa mengakses kiriman-kiriman pengguna Instagram lain, tidak ada batasan kecuali akun yang akan diakses sengaja di private oleh pemilik akunnya. Dari adanya fasilitas ini, semua pengguna Instagram diberikan kebebasan untuk menggunggah foto, video bahkan beserta caption atau keterangan mengenai foto, video apapun yang akan diunggah.

Dari pengamatan yang dilakukan, penyebab terjadinya praktik cyberbullying pada public figure karena unggahan foto atau video public figure yang menurut pengguna tidak sesuai dengan pemikiran mereka. Meskipun unggahan yang menurut mereka "tidak sesuai" itu, jauh dari unsur pornografi atau kekerasan yang jelas ada hukumnya di undang-undang. Dari unggahan yang "tidak sesuai" inilah memunculan komentar-komentar negative yang menyerang akun public figure tersebut. Dibawah ini merupakan data screenshoot praktik cyberbullying, data ini diambil langsung dari akun Instagram milik public figure yang menjadi korban penindasan secara online.

Gambar.1

Gambar. 2

\section{Unggahan Video}
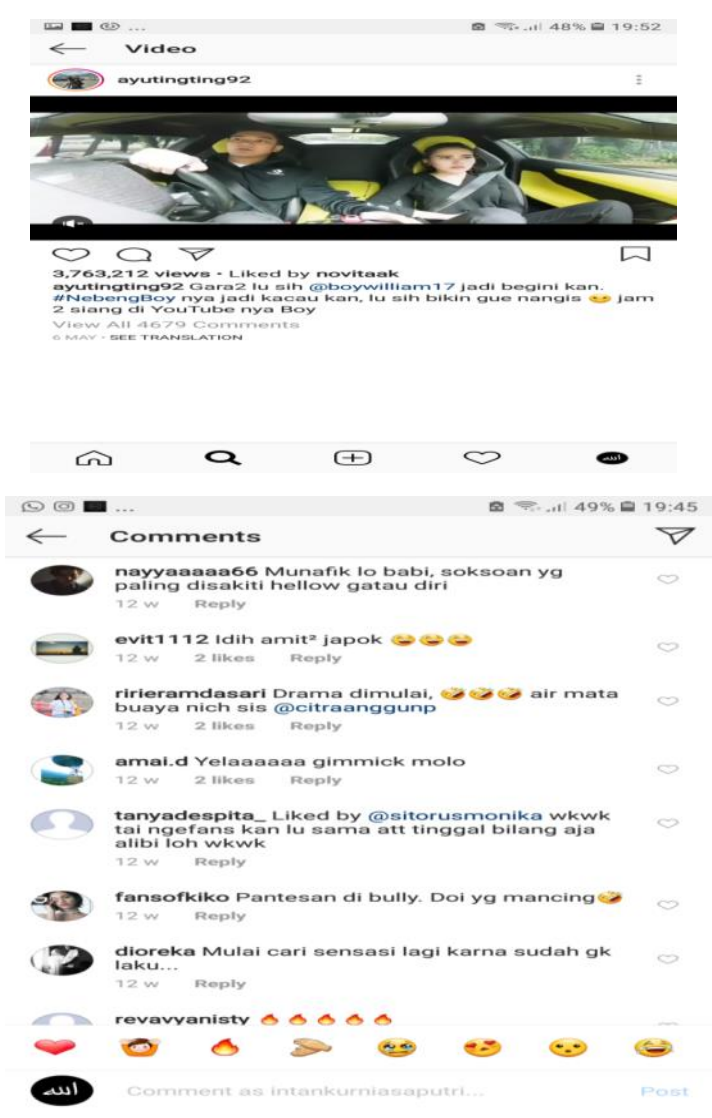

Sumber: diambil dari akun Instagram 


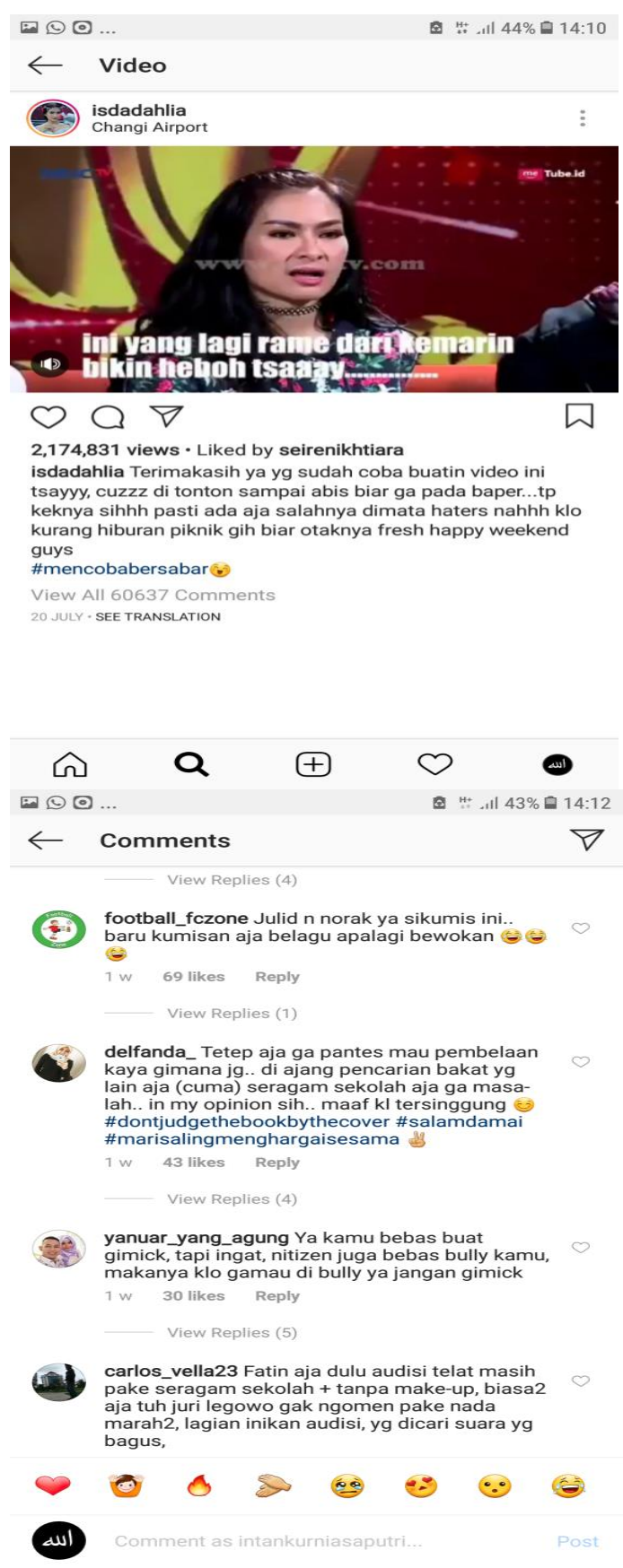

Sumber: diambil dari akun Instagram @isdadahlia ${ }^{22}$

\section{Gambar. 5}

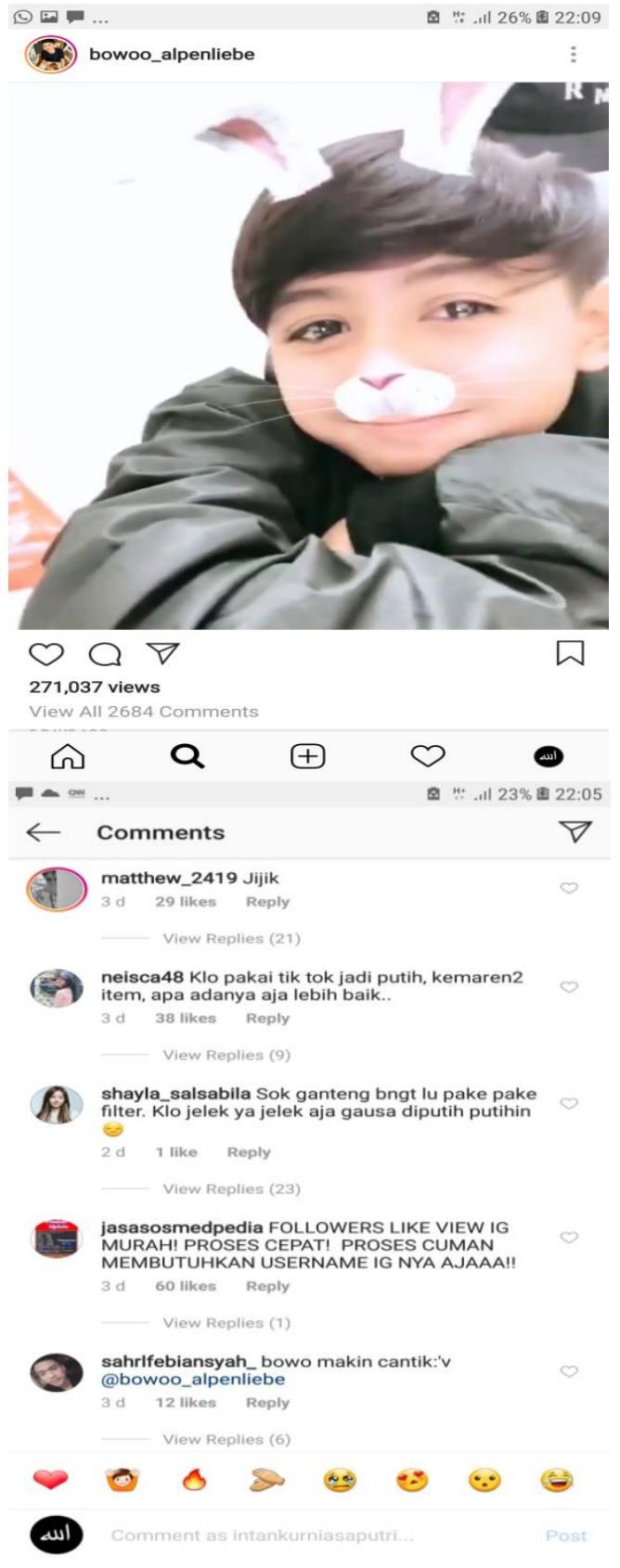

Gambar. 6

Sumber: diambil dari akun Instagram @bowoo_alpenliebe ${ }^{23}$

Seperti yang sudah dijelaskan sebelumnya, Jawkes, Yvoone dan Majid Yar menerangkan bahwa terdapat dua karakteristik cybercrime, yaitu digitalisasi dan anonimitas. $^{24}$ Digitalisasi berarti waktu yang dibutuhkan untuk mengirimkan suatu informasi ataupun data 
sangatla cepat sedangkan anonimitas diartikan sebagai bentuk pertemuan antar pengguna melalui dunia maya. Gambar di atasadalah data yang didapat dari hasil screenshot dibeberapa akun Instagram public figure. Gambar 1 dan 2 merupakan unggahan dari akun Instagram @ayutingting92. Menurut pengamatan penulis komentar-komentar di setiap unggahan akun @ayutingting92 sering di banjiri komentar dengan kata-kata yang mengarah pada bullying. Bergitu juga pada gambar 3, diakun @isdadahlia dan pada gambar 5, diakun @bowoo_alpenliebe.

Jika memahaminya menggunakan salah satu karakteristik dari cybercrime, mereka yang memberi komentar bully-an ini sebenarnya membentuk sebuah keanonimitasan. Dimana, mereka tidak saling kenal secara dekat satu sama lain, hubungan yang terjalin hanya dengan melihat unggahan-unggahan di Instagram saja. Informasi identitas mereka yang membully bisa saja bukan informasi identitas yang sebenarnya. Bisa diartikan bahwa sifat anonimitas ini yang membuat mereka merasa lebih aman ketika melontarkan kata-kata yang kurang pantas. Bukan hanya itu saja, interaksi yang terjadi di internet bukan interaksi yang face to face, sehingga membuat mereka lebih leluasa untuk melontarkan komentarkomentar yang mengarah negatif. Praktik cyberbullying merujuk pada salah satu kejahatan di internet karena bentuk kejahatan ini menggunakan perangkat telekomunikasi modern. Mereka yang berkomentar di akun Instagram public figure, memanfaatkan alat seperti handphone atau computer untuk melakukan kegiatan ini.

Cyberbullying adalah salah satu bentuk dari cybercrime karena merupakan sebuah kejahatan yang menyerang individudan telah ada sanksi hukumnya menurut undang-undang nomor 11 Tahun 2008 tentang Informasi dan Transaksi Elektronik (ITE).Umumnya, praktik cyberbullying ini dilakukan dengan cara pengguna mengomentari unggahan akun instagram dengan adanya unsur mengintimidasi, tulisan yang menyakiti hati, mengancam atau mempermalukan sesama anggota dunia maya. Praktik cyberbullying pada screenshoot kolom komentar diakun Instagram milik @ayutingting92@isdadahlia dan @bowoo_alpenliebe merupak contoh sebagian kecil public figure yang menjadi korban penindasan online.

Dari pengamatan penulis, serangan bullying secara online ini tidak terjadi disetiap unggahan,umumnya pelaku memilih unggahan yang tidak sesuai dengan pemikiran mereka. Misalnya pada kasus di akun Instagram @bowoo_alpenliebe, praktik bullying ini bermula dari pengguna mengganggap 
warna kulit asli@bowoo_alpenliebe tidak sama dengan warna kulitnya ketika berada di Instagram. Di akun Instagramnya, warna kulit@bowoo_alpenliebe berwarna putih dan cerah, sedangkan di dunia nyata warna kulit aslinya berwarna hitam gelap. Sedangkan di akun@isdadahlia,dibanjiri komentar bullying karena@isdadahlia dianggap sombong dan angkuh, ketika dirinya mengusir seorang kontestan diajang pencarian bakat, dan akun @ayutingting92 dibully karena pengguna menganggap @ayutingting92 sering mencari sensasi dan menebarkan gimmic disetiap perjalanan hidupnya.

Ketika pengguna telah mempunyai sebuah topik yang akan menjadi bahan bullyan, maka praktik bullying akan terjadi secara berkala dan terus menerus. Jika diamati, praktik cyberbullying semakin marak terjadi karena semakin banyaknya masyarakat yang menggunakan internet dan bermain sosial media. Mengambil penjelasan mengenai unsur-unsur daripada cyberbullying menurut Cyber Bullying Research Center, yang terdiri dari willful, repeated, harm dan computers, cell phones, and other electronic devices. ${ }^{25}$ Harm diartikan sebagai tindakan atau perilaku yang disengaja. Mereka melakukan praktik bullying dengan berkomentar mengarah ke hal-hal yang negarif dan melakuakannya dengan sadar dan disengaja. Dari kata-kata yang dilontarkan, ada sebuah bentuk kekesalan, amarah dan ketidaksukaan atas apa yang dilakukan oleh korban. Bentuk kekesalan inilah yang dituangkan melalui kata-kata di kolom komentar.

Berdasarkan gambar diatas dan dari pengamatan penulis, kata-kata yang dilontarkan salah satunya menjurus kepada penghinaan dari bentuk kekurangan yang ada di diri korban. Seperti "kulit hitam", "wanita tetapi berkumis", "janda", katakata lain seperti “jijik", "sok ganteng”, dan lain sebagainya. Hal ini menjelaskan bahwa, mereka sebagai pelaku bullying berkomentar dengan sadar dan tidak ada unsur paksaan karena yang mendorong mereka untuk berkomentar dari pemikiran dan diri mereka masing-masing. Sedangkan unsur yang kedua adalah repeated, yang berarti ada sebuah bentuk pengulangan. Tidak hanya sekali dua kali pelaku bullying melontarkan komentar dengan kata-kata negatif, malah ada yang sengaja membuat sebuah akun palsu atau unknown freiends untuk melancarkan praktik bullying.

Dari gambar diatas, dapat kita pahami bahwa jumlah pengguna yang berkomentar rata-rata lebih dari seribu komentar yang jika penulis amati isi dari komentar itu semuanya menjurus pada komentar bullying. Sebuah pengulangan ini lama kelamaan akan menjadi sebuah cerminan perilaku yang dipraktikan terus- 
menerus dan semakin berkembang. Hal mengartikan bahwa, jika sudah ada unsure repeated maka praktik bullying akan sulit dibendung dan dihentikan, karena power dari pengguna sebagai pelaku bullying sangatla kuat. Dibuktikan dengan banyaknya komentar-komentar yang diterima oleh korban yang mencapai seribu malah sampai puluhan ribu. Komentar bullying ini tidak hanya berhenti disebuah unggahan saja, namun terus menerus akan seperti itu pada unggahan berikutnya dan inilah yang dinamakan sebagai praktik bullying yang bukan hanya berupa satu insiden tunggal.

Kemudian unsur harm, unsur ini diartikan sebagai sebuah ancaman, kejahatan atau tindakan yang menyakiti yang ditujukan pada korbanya. Kata-kata dari pengguna di kolom komentar pada gambar di atas merupakan sebuah bentuk tindakan yang menyakiti. Hal ini dibuktikan dengan banyaknya public figure yang melaporkan kasus ini ke pihak yang berwajib. Dengan pengamatan dan pencarian data, diantaranya public figure seperti Ruben Onsu dan Deddy Corbuzier pernah melaporkan kasus cyberbullyingke polisi. Deddy Corbuzier merasa tidak nyaman dengan banyaknya komentarkomentar bully-an yang ditujukan kepadanya. $^{26}$ Sedangkan Ruben Onsu, penghinaan melalui komentar dari pengguna tidak ditujukan kepada dirinya saja, namun juga ditujukan untuk anaknya dan merambat kepenghinaan agama dan SARA. $^{27}$

Selanjutnya, unsur terakhir dari cyberbullying adalah computers, cell phones, and other electronic devices, merupakan sebuah media yang digunakan untuk melakukan tindakan cyberbullying. Pengguna yang berkomentar dengan mengedepankan kata-kata yang menyakiti hati korban bullyan menggunakan perangkat elektronik seperti handphone atau computer untuk melancarkan aksi bullying. Hal inilah yang menjadi salah satu pembeda antara cyberbullying dan bullying tradisional.

Mengambil pemikiran dari Olweus, bahwa bullyingtradisional merupakan kegiatan negatif yang terwujud dalam bentuk kontak fisik, kata-kata/verbal, gerak tubuh dan pengucilan seseorang dari satu kelompok tertentu. ${ }^{28}$ Untuk lebih memamahi kegiatan negatif dalam bullying yang sekarang terjadi pada dunia maya, kita dapat mengambil pemahaman dari hasil penelitian Patchin, dalam penelitian ini Patchin merumuskan 4 jenis cyberbullying, yaitu called name(pemberian nama negatif), Image of Victim (penyebaran foto), Threatened Physical Harm (mengancam keselamatan fisik) dan Opinion Slammed(pendapat merendahkan). ${ }^{29}$ Dari masing-masing jenis cyberbullying ini, penyerangan yang sering 
dilakukan pengguna untuk korban bullying adalah mengutamakan kekuatan verbal, lain halnya dengan bullying tradisional yang umumnya menggunakan kontak fisik dan gerak tubuh.

Dari pengamatan penulis, jenis cyberbullying yang pertama yaitu called name merupakan jenis cyberbullying yang sering digunakan. Bersumber dari akun Instagram@ayutingting92, mereka yang membully @ayutingting lewat kolom komentar sering memanggil @ayutingting92 dengan menggunakan istilah "japok" atau singkatan dari janda depok. Sedangkan pada akun@isdadahlia, pengguna menggunakan istilah "kumis lele". Pemberian nama negatif adalah bentuk serangan cyberbullyingyang bertujuan untuk memberi label buruk terhadap korban.Tidak hanya memberikan label buruk, jenis cyberbullying yang kedua yaitu image of victimjuga dialami oleh @ayutingting92 dan @bowoo_alpenliebe.

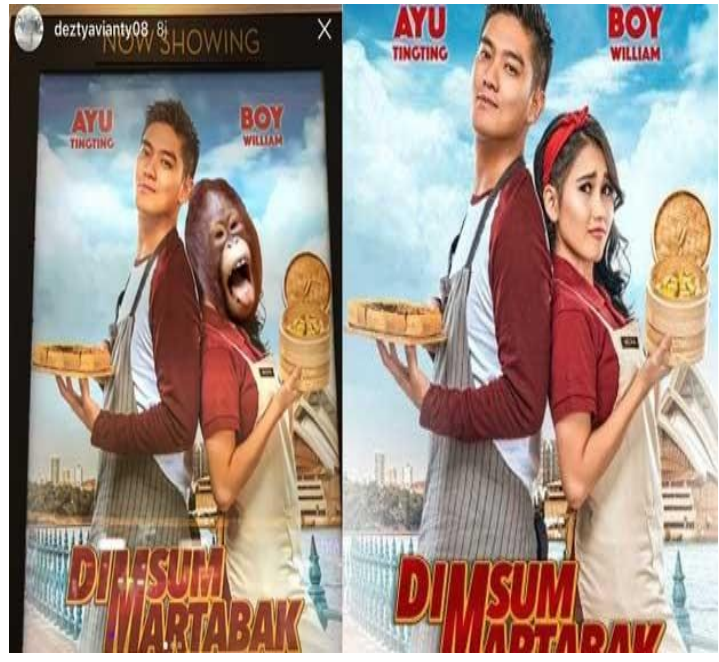

Gambar. 7

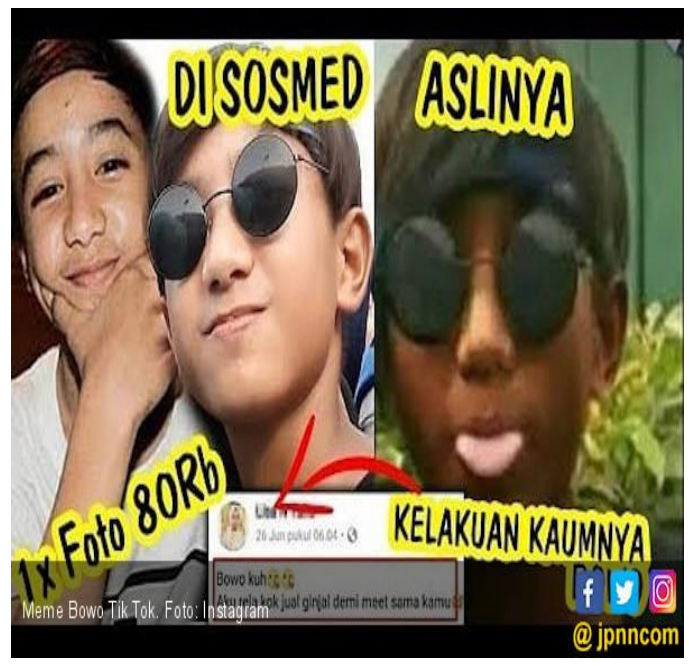

Gambar. 8

Sumber: $\quad$ www.cumi-cumi.com ${ }^{30}$ Sumber: Www.jpnn.com ${ }^{31}$

Gambar diatas adalah contoh beberapa meme yang bisa dipahami bahwa pelaku bullying juga menggunakan istilah image of victim untuk menyerang korbannya. Penggunaan meme merupakan sebuah wujud cyberbullying yang dilakukan untuk merendahkan, menyudutkan korbannya. Meme ini juga 
bisa diartikan sebagai sebuah objek hiburan untuk membully korbannya. Menilik pemahaman olweus, yang mengatakan bahwa bullying merupakan sebuah bentuk agrresive act yaitu adanya sebuah perilaku kekerasan. ${ }^{32}$ Perlu diingat bahwa tidak semua kekerasan termasuk bullying. Suatu hal bisa dikatakan bullying jika terdapat sebuah imbalance of power, yang artinya tidak adanya keseimbangan penyerangan dari satu pihak ke pihak lainnya. Hal ini yang membuat korban mengalami kesulitan untuk melindungi diri dari penyerangan tersebut.

Dalam contoh kasus yang telah dijelaskan diatas, penyebaran image of victim dan pemberian label atau called name merupakan sebuah penyerangan yang dilakukan oleh pengguna. Penyerangan ini tidak hanya dilakukan oleh satu atau dua orang, mengingat bahwa pengguna mendia sosial sangat banyak dan penyebaran informasi dimedia sosialpun sangat cepat. Mereka sebagai korban tidak mempunyai benteng perlawanan yang kuat untuk bertahan terhadap serangan. Inilah yang diartikan sebagai imbalance of power, dibuktikan dengan beberapa public figure yang merasa diserang secara terusmenerus akhirnya melaporkan cyberbullying ke pihak yang berwajib.

Terakhir, salah satu unsur yang harus diperhatikan dalam praktik cyberbullying adalah "power", penjelasan Olweus mengatakan bahwa power dalam cyberbullying mempunyai sifat yang dapat bergeser. ${ }^{33}$ Jika dalam bullying tradisional, power dapat dilihat dari bentuk fisik atau postur dan power secara sosial berupa popularitas. Sedangkan, pada cyberbullying power dapat dilihat dari kemampuan, pengetahuan dan kepemilikan akan beberapa konten yang dapat berupa informasi ataupun gambar yang digunakan untuk melakukan tindakan cyberbullying. Power dalam hal ini misalnya kepemilikan konten dengan menyebarkan meme ataupun foto-foto korban.Power berupa penyebaran konten terkadang juga dilakukan oleh unknown friends yang tidak tidak mudah dilacak identitas aslinya.

\section{Penutup/Kesimpulan}

Adanya fenomena cybercrime yang tidak terlepas dari perkembangan teknologi justru menjadi ancaman bagi penggunanya. Salah satunya fenomena cyberbullying yang dilakukan sesama pengguna internet.Cyberbullying mempunyai 4 unsur, yaitu "willful" yang berarti perilaku atau tindakan yang disengaja, "repeated" yang berarti diulang-ulang dan mencerminkan sebuah pola perilaku, "harm" yang memiliki arti sebagai sebuah ancaman, kejahatan atau tindakan yang menyakiti yang ditujukan pada korbannya, danunsur "computers, cell phones, and other electronic devices" merupakan sebuah media yang dipakai 
untuk melakukan tindakan cyberbullying. Didalam kejahata cyberbulling terdapat power, power disini dapat bergeser. Power pada cyberbullying berasal dari kemampuan, pengetahuan dan juga kepemilikan akan beberapa konten yang dapat berupa informasi ataupun gambar yang digunakan untuk melakukan tindakan cyberbullying. Korban cyberbullying cenderung tidak dapat melidungi dirinya sendiri, dikarenakan adanya imbalance power. Dalam banyak cara, efek "harm" yang ditimbulkan dari cyberbullying lebih berbahaya dikarenakan adanya anonimitas dalam internet yang memungkinkan para pelaku cyberbullying dapat menutupi identitas dirinya.

Endnote

${ }^{1}$ Everett MRogers. 1986. Communication

Technology: the New Media in Society. New York: The Free Press

${ }^{2}$ Flew. 2005. New Media: An Introduction. Second Editio. Oxford: Oxford University Press.

${ }^{3}$ Everett MRogers,. 1986. Communication

Technology: the New Media in Society. New York. The Free Press

${ }^{4}$ Jewkes, Yvoone and Majid Yar. 2011. Handbook of Internet

Crime.http://samples.sainsburysebooks.co.uk/9781 134030590_sample_822906.pdf. Diakses 25 Juli 2018

${ }^{5}$ Brown, Cameron. S. D. 2015. Investigating and Prosecuting Cyber Crime:Forensic Dependencies and Barriers to Justice. International Journal of
Cyber Criminology Vol 9. Australia: Australian National University.

http://www.cybercrimejournal.com/Brown2015vol 9issue1.pdf. Diakses 25Juli 2018

${ }^{6}$ Singh Poonia, Ajeet. Dr. 2014. Cyber Crime:

Challenges and its Classification. International Journal of Emerging Trends \& Technology in Computer Science (IJETTCS) Vol. 3. Issue. 6. India: Govt. College of Engineering and Technology, Bikaner. http://www.ijettcs.org/Volume3Issue6/IJETTCS2014-12-08-96.pdf. Diakses 27Juli 2018

${ }^{7}$ Jewkes, Yvoone and Majid Yar. 2011. Handbook of Internet Crime.

http://samples.sainsburysebooks.co.uk/9781134030 590_sample_822906.pdf. Diakses 25Juli 2018

${ }^{8}$ ibid

${ }^{9}$ ibid

${ }^{10}$ ibid

${ }^{11}$ ibid

${ }^{12}$ Singh Poonia, Ajeet. Dr. 2014. Cyber Crime:

Challenges and its Classification. International Journal of Emerging Trends \& Technology in Computer Science (IJETTCS) Vol. 3. Issue. 6. India: Govt. College of Engineering and Technology, Bikaner.

http://www.ijettcs.org/Volume3Issue6/IJETTCS2014-12-08-96.pdf. Diakses 27 Juli 2018

${ }^{13}$ Hinduja, S \&Patchin, J. W. 2014. Cyberbullying: Identification, Prevention, \& Response. Cyber Bullying Research Center.

http://cyberbullying.org/CyberbullyingIdentification-Prevention-Response.pdf. Diakses 28 Juli 2018

${ }^{14}$ Nicole Hines, Heather. 2011. Traditional Bullying And Cyber-Bullying: Are The Impacts On Self-Concept The Same?. Western Carolina University. https://libres.uncg.edu/ir/wcu/f/Hines2011.pdf. Diakses 28 Juli 2018 
${ }^{15}$ ibid

16 ibid

${ }^{17}$ Unicef Indonesia. Studi Terakhir: Kebanyakan

Anak Indonesia sudah online, namun masih banyak yang tidak menyadari potensi resikonya.

https://www.unicef.org/indonesia/id/media_22169. html. diakses pada 29 Juli 2018

${ }^{18}$ Ipsos. One in Ten (12\%) Parents Online, Around the WorldSay Their Child Has Been Cyberbullied,

26\% Say They Know of a Child Who Has

Experienced Same in Their Community.

https://www.ipsos.com/sites/default/files/news_and _polls/2012-01/5462rev1.pdf. diakses pada 29 Juli 2018

${ }^{19}$ KBBI. https://artikbbi.com/figur/. Diakses 29 Juli 2018

${ }^{20}$ Wilkinson, J. S., McClung, S. R., \& Sherring, V. A. 2009. The Converged Audience: ReceiverSenders and Content Creators. In J. W. August E. Grant, Understanding MediaConvergence: The State of the Field. NY: Oxford University Press.

${ }^{21}$ The Jakarta Post. Indonesia Instagram's Biggest

Market in Asia Pacific.

http://www.thejakartapost.com/life/2017/07/26/ind onesia-instagrams-biggest-market-in-asiapacific.html. diakses 28 Juli 2018

${ }^{22}$ Instagram. Iis Dahlia.

https://www.instagram.com/isdadahlia/?hl=id.

Diakses 30 Juli 2018

${ }^{23}$ Instagram. PrabowoMdr.

https://www.instagram.com/bowoo_alpenliebe/?hl= id. Diakses 30 Juli 2018

${ }^{24}$ Jewkes, Yvoone and Majid Yar. 2011. Handbook of Internet

Crime.http://samples.sainsburysebooks.co.uk/9781 134030590_sample_822906.pdf. Diakses 25 Juli 2018

${ }^{25}$ Hinduja, S \&Patchin, J. W. 2014. Cyberbullying: Identification, Prevention, \& Response. Cyber Bullying Research Center.
http://cyberbullying.org/Cyberbullying-

Identification-Prevention-Response.pdf. Diakses 28 Juli 2018

${ }^{26}$ Sapto Purnomo. Deddy Corbuzier Seret Heter ke

Polisi.https://www.liputan6.com/showbiz/read/243

1363/deddy-corbuzier-seret-hater-ke-polisi. diakses

1 Agustus 2018

${ }^{27}$ Alan Pamungkas. Diserang Haters, Ruben Onsu

Ikut Lapor Polisi.

https://celebrity.okezone.com/read/2015/08/14/33/1

196494/dihina-haters-ruben-onsu-ikut-lapor-polisi.

Diakses 1 Agustus 2018

${ }^{28}$ Nicole Hines, Heather. 2011. Traditional Bullying And Cyber-Bullying: Are The Impacts On SelfConcept The Same?. Western Carolina University. https://libres.uncg.edu/ir/wcu/f/Hines2011.pdf. Diakses 28 Juli 2018

${ }^{29}$ Patchin, Justin W. \& Sameer Hinduja. 2012.

CyberbullyingPrevention And Response: Expert

Perspectives. New York: Routledge

${ }^{30}$ Cumicumi.com. Edit Wajah Ayu Ting Ting Jadi

Orang Utan, Pelaku Terciduk dan Minta Maaf.

http://www.cumicumi.com/news/cumi-

celebs/146639/edit-wajah-ayu-ting-ting-jadi-orangutan-pelaku-terciduk-dan-minta-maaf. diakses 2

Agustus 2018

${ }^{31}$ Jpnn.com. Ngeri, Ibu Bowo TikTok Berhenti

Kerja Gara-gara ini.

https://www.jpnn.com/news/ngeri-ibu-bowo-tiktok-berhenti-kerja-gegara-ini. diakses 2 Agustus 2018

${ }^{32}$ Nicole Hines, Heather. 2011. Traditional

Bullying And Cyber-Bullying: Are The Impacts On

Self-Concept The Same?. Western Carolina

University.

https://libres.uncg.edu/ir/wcu/f/Hines2011.pdf.

Diakses 28 Juli 2018

${ }^{33}$ ibid 